\title{
The Productivity Problem
}

\author{
JOHN A. TATOM
}

T.

HE American economy has been plagued by numerous economic problems during the seventies. Of particular importance, of course, are the relatively high inflation and unemployment rates, the changing and growing influence of government in individual lives, and problems associated with the dramatic rise in energy prices. Such issues have been widely recognized during this decade.

One fundamental problem, however, has just recently begun to attract increasing attention - the slow growth of U.S. labor productivity in the seventies. The Joint Economic Committee in its 1979 Midyear Report refers to lagging productivity growth as the "Linchpin of the Eighties."1 Likewise, a recent examination of the major economic issues in 1979 begins with five studies on the productivity problem. ${ }^{2}$ Despite the recent flurry of attention, however, there appears to be no consensus on the source of the slowdown, its signficance, its impact on the economy or economic policy, or the possibility or desirability of policy reactions to the problem. ${ }^{3}$

Since productivity developments in the seventies appear to be a puzzle, it is useful to examine carefully the explanations that have been advanced in search

\footnotetext{
1See Joint Economic Committee, Outlook 1980's Midyear Report and Staff Study, U.S. Congress, 96th Cong., (August 1979).

¿See William Fellner, Project Director, Contemporary Economic Problems 1979, American Enterprise Institute for Public Policy Research, 1979.

BFor exarnple, the four factors cited most frequently at a recent conference on productivity were a decline in capital investment, a slowing in the introduction of new technology, the changing composition of the labor force toward relatively more inexperienced groups, and an increase in service employment relative to manufacturing employment. Barry Bosworth, head of the President's Council on Wage and Price Stability at the time, however, demonstrated that these explanations are not significant in explaining the extent of the current productivity problem. See the discussion of the conference by Bradley Graham "Productivity Problem Outlined" Washington Post, October 4,1978 . The article also points out
}

of a clue. ${ }^{4}$ Such an examination shows why the productivity problem has only recently been generally recognized and provides insight into the role of government policy in reversing the adverse productivity developments of the seventies. Prior to considering the various hypotheses about recent productivity developments, a brief review of what is meant by productivity, the sources of its growth, and recent productivity developments is necessary.

\section{PROMUCIIITI ANO

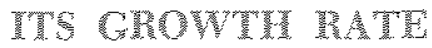

Productivity is a concept which relates the output of a production process to the inputs used in the process. There are several ways to view productivity since, in most processes, several resources are used. One may refer to labor productivity, which is the output obtained per worker employed or per hour of work. Similarly, the productivity of other resources, such as physical capital or energy, may also be of interest. A more general notion is that of total factor productivity which relates output to the entire set of physical resources used in the production process by assigning a weight to each resource employed based on its relative importance in the production process.

\footnotetext{
that while Robert Strauss, then special assistant to the President on inflation and trade policy, noted at the conference that "Productivity is a terrible problem for this nation," the government's National Center for Productivity and the Quality of Working Life, an institution chartered at the beginning of this decade to study and promote productivity, was allowed to go out of existence in October 1978.

4Edward F. Denison, "Explanations of Declining Productivity Growth," Survey of Current Business (August 1979), pp. 1.24, examines 17 factors which might account for the productivity decline and finds them insufficient to explain the puzzle. Several of the factors he considers and rejects, including, for example, the "people don"t want to work any more" hypothesis, are not discussed here. Denison's views differ from those presented here in that he dismisses both energy developments and slow growth of the capital stock as factors responsible for the decline.
} 
One may understand more clearly the different views of productivity by considering the production process itself. In any production process, output is obtained by organizing the use of various resources and utilizing a given technology. Output may be increased by using more resources, by improving the organization of the producing unit, or by introducing an improved technology. If more output is obtained through improved organization or technology without changing the level of resource use, total factor productivity (the output per unit of resources employed) and the output per unit of any single resource used will increase.

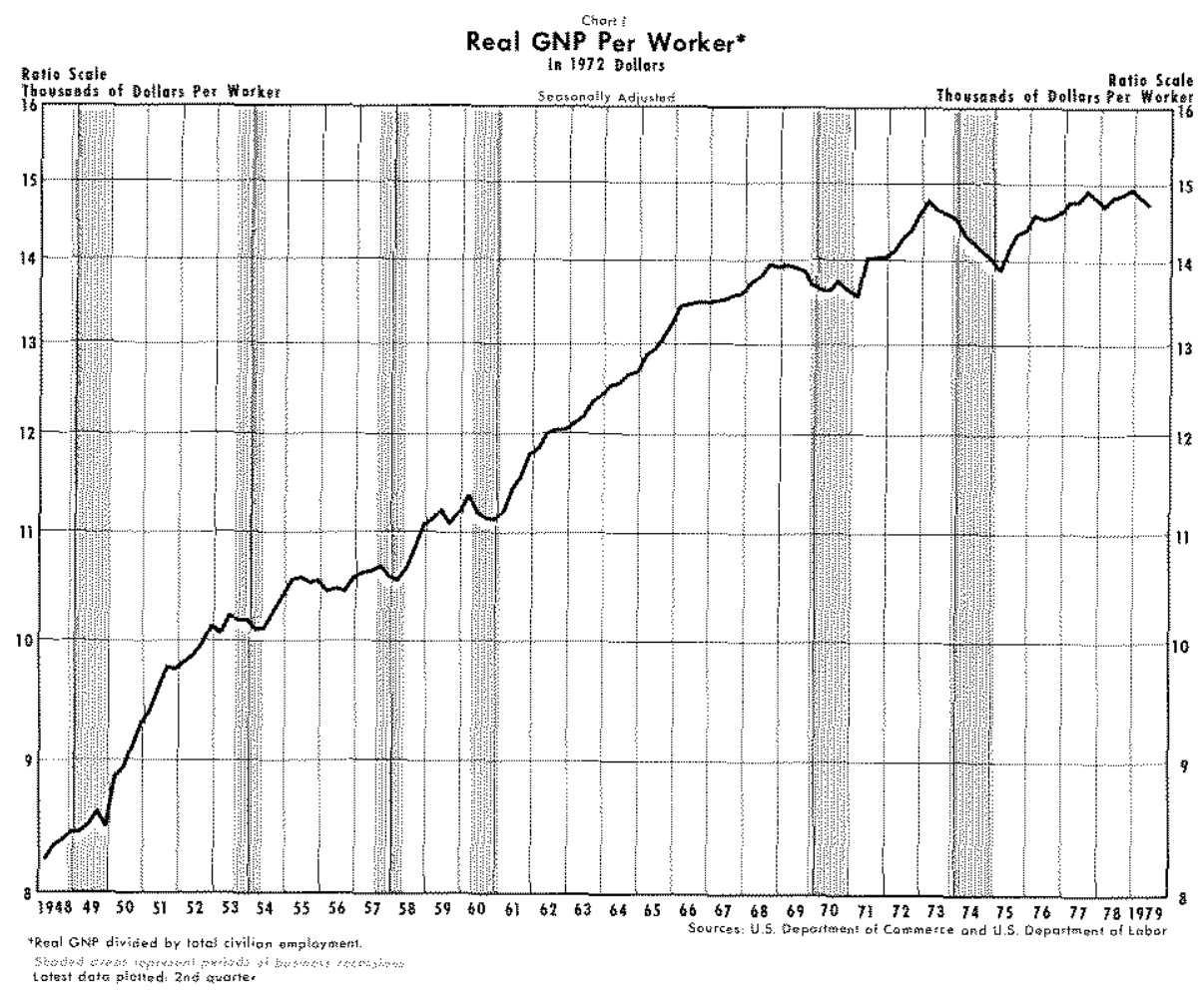

Output may be increased, however, by simply using more of a specific resource, such as labor, without altering the methods of organization, the technology, or the use of other resources. In this case, the output obtained per unit of other resources rises, so their productivity is higher. Whether ontput rises relatively more or less than the increase in labor employment determines how the productivity of labor changes. According to the "principle of diminishing returns," the productivity of labor in such an example falls because the amount of other resources used per unit of labor declines.

The analysis of productivity usually focuses on measures of the productivity of labor. For the firm, output per worker (or per hour) is important because labor costs represent a major share of the total cost of production. Consequently, changes in output per worker have an important bearing on employment and output decisions, as well as on wages and prices. Improvements in labor productivity tend to lower unit costs of output, and provide incentives for firms to expand production. This, in turn, tends to result in lower output prices (relative to those of other goods and services) and/or higher wages for employees.

Labor productivity growth is also important at an aggregate level, primarily as a reflection of economic

growth. Real income in an economy is often viewed as the product of the size of the working population and output per worker. Thus, growth in real income per capita is primarily determined by labor productivity growth. The only other source of change of real income per capita - a change in the percentage of the population that is working - varies over the business cycle because of fluctuations in employment, but does not show any systematic tendency to increase. ${ }^{\bar{j}}$ Moreover, gains in real income per capita from this source come at the expense of leisure and home production, unlike productivity improvements which permit increases in both nonmarket (for example, leisure) and market income.

According to the discussion above, labor produc-

Since World War II, the ratio of civilian employment to the civilian noninstitutional. population of age 16 and over has reached about 58 percent at the peak of periods of economic expansion. In the recent expansion, this ratio rose slightly above 60 percent. In 1969 it was 58.0 percent, while in 1978 it was 59.4 percent. This difference given a constant level of labor productivity and population, accounts for about 27 percent of the average annual real GNP growth rate of 2.93 percent over the period. Herbert Stein, "Why Did Consumption Not Reflect the Slackening of the Productivity Trend," American Enterprise Institute Economist (June 1979), reprinted in Fellner, Contemporary Problems, pp. 13-15, has noted that much of the productivity slowdown of the seventies was compensated for by increased partictpation in the labor force so that growth of real GNP per capita did not slow as much. 

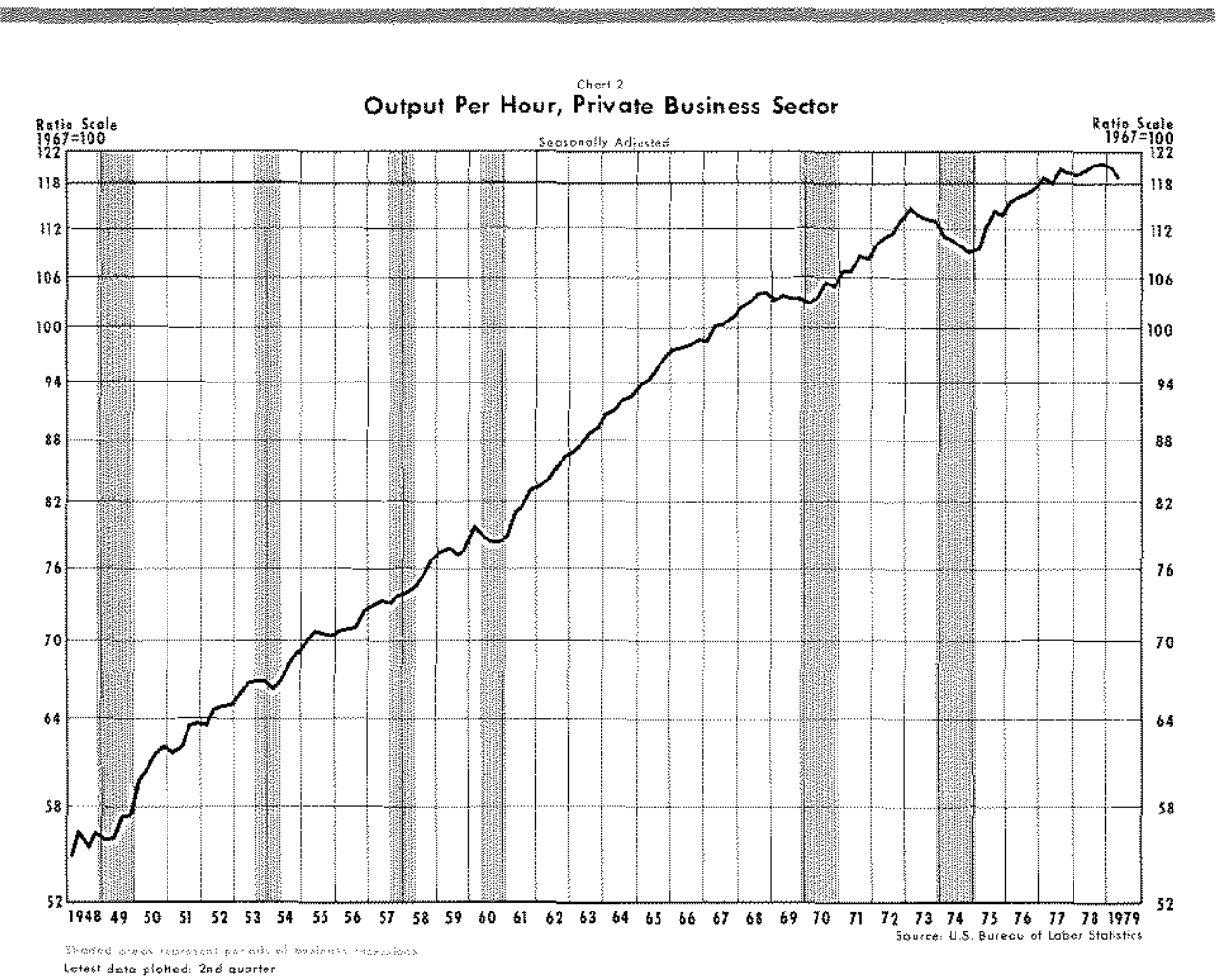

Productivity growth in the seventies, particularly since 1973, has been extremely sluggish. From 1948 to early 1973 , the trend rate of growth of real GNP per worker was 2.4 percent per year; since then, the average annual rate of growth has been essentially zero. The same pattern appears in Chart 2 where the trend rate of growth was 3.0 percent per year until the first quarter of 1973, while the recent rate has been 0.5 percent. In both cases, productivity declined sharply during 197374 and, despite the relatively rapid expansion of output and employment since 1975 , the rate of productivity growth has remained unusually slow. tivity is improved by increasing the employment of other resources used by workers, or by improving organization or the technology used in production. Examples of the sources of such changes are increases in the skill, experience, or health of workers; increases in the availability or quality of resources such as physical plant, equipment, and energy; successful research and development efforts; and the breaking down of artificial barriers to the use of resources such as labor in activities where productivity would be higher.

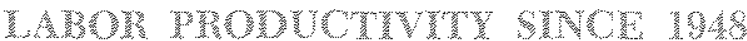

Numerous measures of labor productivity in the U.S. economy can be obtained depending upon the choice of alternative measures of aggregate output and labor employment such as hours or the number of workers. Charts 1 and 2 show two of these measures. Chart 1 shows real GNP divided by the quarterly average of civilian employment, while Chart 2 shows output per hour in the private business sector, which excludes output originating in governmental units, households, nomprofit organizations, and the rest of the world. In both cases, the productivity measure is shown from 1948 to the present. ${ }^{6}$

The charts show the logarithm of productivtty to indicate trends in growth. Throughout this article, growtl rates are
The difference in growth rates in the two charts primarily reflects a systematic decline in hours of employment per worker. The average annual rate of decrease in hours per worker from 1947 to the present, which is 0.4 percent per year, accounts for almost all of the difference in growth rates. ${ }^{7}$

\section{W

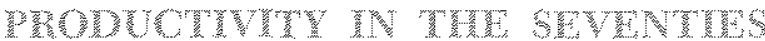

Many explanations have been given for the disappointing performance of productivity in the seventies. While it is not possible to empirically assess the role of each factor, and while considerable disagreement exists about their relative importance, a discussion of them can provide some insight into the problem.

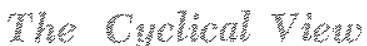

Until recently, the consensus was that the productivity problem was due to the stage of the business

measured by changes in logarithms of variables to provide symmetry and ease of calculation. This is a standard approxination of rates of growth.

This trend is found by regressing cuarterly hours per worker in the private business sector on a constant, the unemployment rate, and a time trend for the period $1 / 1948-11 / 1979$. The unemployment rate is inciuded to acoount for a significant negative relationship between hours per worker and unemployment. 
cycle and was, therefore, temporary. Productivity growth usually slows during high-employment periods and recessions. During recoveries, however, productivity growth generally speeds up, restoring productivity to the previous trend growth path (see Charts 1 and 2). Unfortunately, such a recovery did not occur during the recent economic expansion.

The rationale for cyclical productivity movements is that firms practice "labor hoarding." During recession, firms are reluctant to lay off workers since they want to avoid the relatively large rehiring costs in the subsequent expansion. Similarly, output increases in the early stage of expansions are readily achieved, increasing output by increasing the utilization of labor at a given employment level. Thus, cyclical variation in output is larger than that in employment.

It has also been observed that hours of employment per worker display a cyclical pattern. Output declines during a downturn are achieved by reducing hours per worker rather than by simply reducing the number of employees. As a result, productivity measured relative to employment varies over the cycle more than output per hour. A related point often encountered in discussions of cyclical productivity is that some portion of labor employment is of the overhead variety, such as management; normally, as output changes over the cycle, little change in overhead labor employment occurs. As a result, productivity varies procyclically. ${ }^{8}$

Another explanation of cyclical labor productivity is simpler and, in most respects, compatible with the "labor hoarding" view. This explanation is that the use of capital relative to labor is procyclical — firms use relatively more capital-intensive methods as the economy expands and reduce capital usage relative to labor during economic contractions. Consequently, output changes relatively more than labor employment over the cycle, and labor productivity is procyclical. ${ }^{9}$

8A discussion of these arguments may be found in many text books. For example, see Rudiger Dormbusch and Stanley Fischer, Macroeconomics (New York: McGraw-Hill, Ine, 1978), pp. 348-9. They cite productivity developments in 1974-75 as an illustration of such an argument.

This explanation of cyclical productivity and evidence supporting it is presented more fully in John A. Tatom, "The 'Problem' of Procyclical Real Wages and Productivity," Journal of Political Ecotiomt (February 1980), forthcoming. This explanation differs from the labor-hoarding argument primarily because of its implications. Discussions of labor hoarding often appear to imply that workers are allowed to idle about awaiting the recovery and that, consequently, output represents a departure from the normal production relationship linking output to labor employment. Such an implication is unwartanted once the cyclical pattern of resource em-
A recent example of cyclical changes in labor productivity occurred prior to the 1970 recession. From the fourth quarter of 1964 to the first quarter of 1969 , the economy operated under high-employment conditions, and real GNP per worker grew at an average rate of 2.2 percent per year (roughly the postwar average). During the next three quarters, productivity declined at a 1.5 percent rate, and during the four quarters of the subsequent recession, this measure of productivity declined at a 0.5 percent rate. In the ensuing expansion period, however, productivity initially grew faster than average. From the end of 1970 (the cyclical trough) to the first quarter of 1973, real GNP per worker expanded at a 3.6 percent rate and employment was restored to essentially a high-employment rate. Thus, an average annual rate of growth of 1.9 percent was achieved from the end of 1964 to early 1973, not much below the rate of expansion prior to the recession.

Starting from high-employment conditions early in 1973, the cyclical explanation subsequently proved inadequate. Productivity declined at a 2.1 percent rate during the three quarters prior to the cyclical peak in the fourth quarter of 1973 . During the recession (IV/1973-I/1975), real GNP per worker declined at a 3.3 percent rate. During the recovery, productivity rose faster than the prior trend rate, recovering some of the cyclical loss, but the cyclical resurgence of labor productivity soon abated leaving the productivity growth path well below its prior trend. From the trough quarter $(I / 1975)$ to the second quarter of 1979 , real GNP per worker rose at only a 1.4 percent rate, leaving the level of productivity below that of the first quarter of 1973.

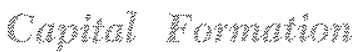

Another major hypothesis is that the productivity problem results from a slowing in the pace of capital formation and/or inefficiencies in the allocation of new capital expenditures.

Growth of the net stock of nonresidential plant and equipment slowed after 1973, a decline that is especially pronounced when related to growth in the labor force over this period. ${ }^{10}$ Growth of the high-

ployment is taker into account. Just as increasing the use of capital adds to output and labor productivity on a trend basis, cyclical variations in the mix of resources employed account for temporary movements in labor productivity over the cycle. There are no unusual departures of productivity from the basic empirical relationship between output and the use of labor and capital resources in the U.S. economy.

1. See John A. Tatom, "Erergy Prices and Capital Formation: 1972-77," this Review (May 1979), pp. 2-9. Denison "Explanation of Dedining Productivity Crowth, p. 3, shows 
employment net capital stock per worker has practically halted when compared with the trend rate of growth of 2.9 percent per year from 1950 to mid-1972. From mid-1972 to mid-1979, capital per worker grew at a 0.6 percent rate, leaving the level of capital per worker by mid-1979 about 17 percent lower than that implied along the 1950-72 trend. Alternately, the net capital stock was about $\$ 200$ billion (1972 prices) lower than would have existed if the previous trend rate of growth had been achieved. A 17 percent loss in capital per worker would reduce private business sector output per hottr by approximately 4.8 percent.

Distributing the 4.8 percent decline in output associated with these capital formation developments over the seven years, however, yields a 0.7 percent decline per year, while the growth rate of output per hour slowed from 2.8 percent from I/1950-II/1972 to 1,0 percent from mid-1972 to mid-1979. A sizeable estimate of the reduction in productivity growth due to the slowing in capital formation has also been made for the nonfarm business sector during the period 1973-77.11 Capital formation has played a major role in the stagnation of productivity growth in the 1970s. Considered alone, however, it does not appear to account fully for the extent of adverse developments.

There are reasons to believe that estimates of the role of slower capital formation may understate its actual impact. First, it is likely that the net stock of fixed nonresidential capital estimated by the Bureau of Economic Analysis does not adequately capture important changes in the capital formation process in the last decade. ${ }^{12}$ In particular, the sharp increase in the rel-

virtually no slowing in the contribution of capital per person employed during 1973-76. The reason for this discrepancy apparently is due to his method of grouping factors which affect productivity and the cyclical differences between 1948 and 1973, on the one hand, and 1973 and 1976, on the other. As Denison points out, in each of the two periods capital per person enployed grew at close to the same rate. Capital per hout of all persons employed slowed sharply, however, due to cyclical differences which show up elsewhere in Denison's groupings. Corrected for cyclical effects, the growth of capital per worker and capital per hour show a sharp decline in capital accumulation.

i1See J. R. Norsworthy and Michael J. Hamer, "The Rote of Capital Formation in the Recent Productivity Slowdown," Bureau of Labor Statistics, U.S. Department of Labor Working Paper 87, (January 1979), Table IV. They also provide evidence refuting the claim that labor productivity growth slowed from 1965 to 1973 due to a slowing in capital stock growth. This claim has heen made by Peter $\mathbf{K}$. Clark, "Capital Formation and the Recent Productivity Slowdown," The Joutnal of Finance (June 1978), pp.965-75. Such evidence may also be seen in Chart IV, in John A. Tatom, "Energy Prices and Capital Formation," p. 7 .

12This data is described by John C. Musgrave, "Fixed Non" residential Business and Residential Capital in the United States, 1925-75," Sturvey of Current Business (April 1976), pp. $46-52$, and" Tatom, "Ënergy Prices and Capital Formation, p. 5 . ative price of energy resources rendered some of the nation's capital stock obsolete. To the extent that estimated series do not capture these losses in normal measures of "discards" and depreciation, the net capital stock measures lead to an overstatement of the growth of the net capital stock in the seventies. ${ }^{13}$

A second difficulty with existing measures is that since the late $1960 \mathrm{~s}$, some investment in business plant and equipment has been made for pollution abatement purposes. Since it is questionable to what extent, if any, such capital formation is "productive" of measured output (as opposed to a cleaner environment), the net capital stock measures may overstate the growth of plant and equipment used by workers to produce market output. Studies generally have indicated, however, that pollution abatement investment has had little effect on the growth of the capital stock or on labor productivity.14 $\mathrm{Ed}$ ward F. Denison has estimated the impact of pollution abatement capital on productivity growth to be quite small; since he accounts for this reduction by reducing the trend growth of total factor productivity, rather than by reducing the size of the capital stock, his results are discussed below.

There are many reasons for the slow pace of capital formation. Explanations usually emphasize the extent of slack in the economy's use of existing resources, the diversion of funds from investment in new plant and equipment to expenditures on health, safety, clean air and water, and large federal budget

13The heory of capacity and capacity losses due to a higher relative price for energy resources is discussed in Robert $H$. Rasche and John A. Tatom, "The Effects of the New Energy, Regime and Economic Capacity, Production, and Prices," this Review (May 1977), pp. 2-12. This article.indicates that the bias that overstates capital stock or capacity measures is likely to monderstate capacity utilization rate measures. Thus, utilized capital meastres that use a product of a utilization rate and a capital stock measure are unilikely to be biased.

1t For example, Robert H. Rasche and John A. Tatom, "Energy Resources and Potential GNP," this Review (June 1977), pp. 10-24, found no significant differences between productivity estimates using capital stock adjusted and thot adjusted for pollution abatenaent capital, p. I5. Similarly, the growh rate of an adjusted capital stock series reported by Peter K. Clark, "A New Estimate of Potential GNP," U.S. Congress, Joint Economic Commitlee, Hearings on the leconomic Report of the President, 95 th Congress, 1 st sess., Jannary 19 , 1977, pp. 39-54, is essentially the same from $1968-7 \%$, when the adjustments are present, as during the period 1954-68. A calculation of the capital stock in manufacturing, with and without adjustment for pollution abatement capial, by Lawrence I. Forest, Jr., "Capacity Utilization: A Discussion of Concepts and Selected Analytical Applications, Meastures of Capacity Utilization Problems and Tasks, Staff Studies No. 105, Boand of Governors of the Federal Reserve System, (July 1979) pp. 57-135, shows roughy a -3 percent decline in the annual rate of capital formation due to the adjusment from 1968 to 1977 . Such a difference, one of the largest observed, has negligible effects on output per hour. 
deficits which have drained funds otherwise available for new capital projects.

Inflation is also an important source of reduced business capital formation. First, higher rates of inflation tend to reduce the purchasing power of fixed dollar depreciation expenses which results in lower real cash returns in future periods. Also, the U.S. tax system treats interest payments made by firms as income to recipients and taxes it accordingly. When interest rates rise to compensate investors for the steady loss in purchasing power of original sums lent to firms, these receipts - which are necessary to maintain the real wealth of investors - are erroneously treated as income. Consequently, higher before-tax real rates of return are required to compensate for these taxes, further reducing incentives for firms to raise investment funds. Finally, higher inflation rates tend to increase uncertainty about the future inflation rate. Consequently, investors and firms view the cash flows expected from investment projects as riskier and are more reluctant to invest. ${ }^{15}$

This analysis reverses the traditional view of the relationship between productivity growth and infla tion. Until the seventies, the link was considered to run from productivity to inflation, instead of from inflation, via capital formation effects, to productivity growth. According to the earlier view, inflation is largely the result of labor costs growing faster than productivity. Consequently, inflation accelerates when productivity growth slows. In the long run, however, productivity growth determines the growth of wages relative to prices, but the rate of advance of prices including prices of labor services, is largely determined by money growth. Thus, monetary policy is an important influence not only on the rate of increase of prices (including wages) but also, through the effect higher inflation rates have on capital formation and trend productivity growth, on the relative rate of advance of wages compared with prices.

Finally, the sharp rise in the relative price of energy since 1973 has been a major factor in the reduced pace of capital formation. When the price of energy rises relatively more than the price of business output, firms find that the real net cash flows expected from plant and equipment are smaller because of higher operating costs. Moreover, to the extent that the production of capital goods is relatively more energy-

\footnotetext{
15Bution G. Malkiel, "Productivity - the Problem Behind the Headlines," Harvard Business Review (May-June 1979) pp. 81-91, presents evidence of higher risk premiums built into stock and bond returns during the nid-seventies, as well as a discussion of some of the other factors inhibiting capital formation and productivity growth.
}

intensive than the production of other products, a rise in energy prices raises the costs of capital goods relative to the future prices of the products that these capital goods eventually will produce. Taken together, these forces create incentives to reduce energy, plant, and equipment usage per unit of output, by employing less energy per unit of capital and more labor intensive methods of production. This effect has been shown to be quite substantial in temporarily reducing the growth of plant and equipment. ${ }^{16}$

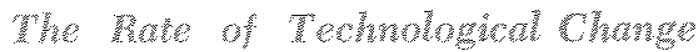

Another important factor influencing productivity is the rate of technological progress, which conceptually represents improvements in total factor productivity not captured in measures of factors of production. For example, improvements in the quality of productive plant and equipment are not necessarily captured in standard measures of the capital stock. Also, improvements in organization or technology (which represent additions to the nation's capital stock) are not always embodied in plant and equipment measures. The contribution of these factors, as well as qualita tive changes in other physical resources, often are assessed by including a time trend in productivity studies to capture the secular rate of productivity change not measured by growth in the use of physical resources.

Clark estimates that the trend rate of growth of total factor productivity in the private business sector was 1.9 percent per year from $1947-66$, but slowed to a 1.4 percent rate after 1966 . He attributes this reduction to a slowing in the rate at which resources have shifted from agriculture to nonfarm business. ${ }^{17}$ Rasche and Tatom find that the productivity trend rate was 1.6 percent in the private business sector from 1949-75; they provide some evidence supporting a smaller trend slowdown after $1966 .{ }^{18}$

An important factor that influences the trend rate of productivity growth is the increase in the stock of knowledge accumulated through research and development outlays. ${ }^{19}$ While it is difficult to assess its

16See Tatom, "Energy Prices and Capital Formation," and Edward A. Hudson and Dale W. Jorgenson, "Energy Prices and the U.S. Economy, 1972-1976," Natural Resources Jour. nal (October 1978), pp. 877-97.

17See Clark, "A New Estimate of Potential GNP."

18See Rasche and Tatom, "Energy Resources and Potential GNP," pp. 16, 19.

${ }^{19} \mathrm{John} W$, Kendrick, "Productivity Trends and the Recent Slowdown: Historical Perspective, Causal Factors, and Pol- 


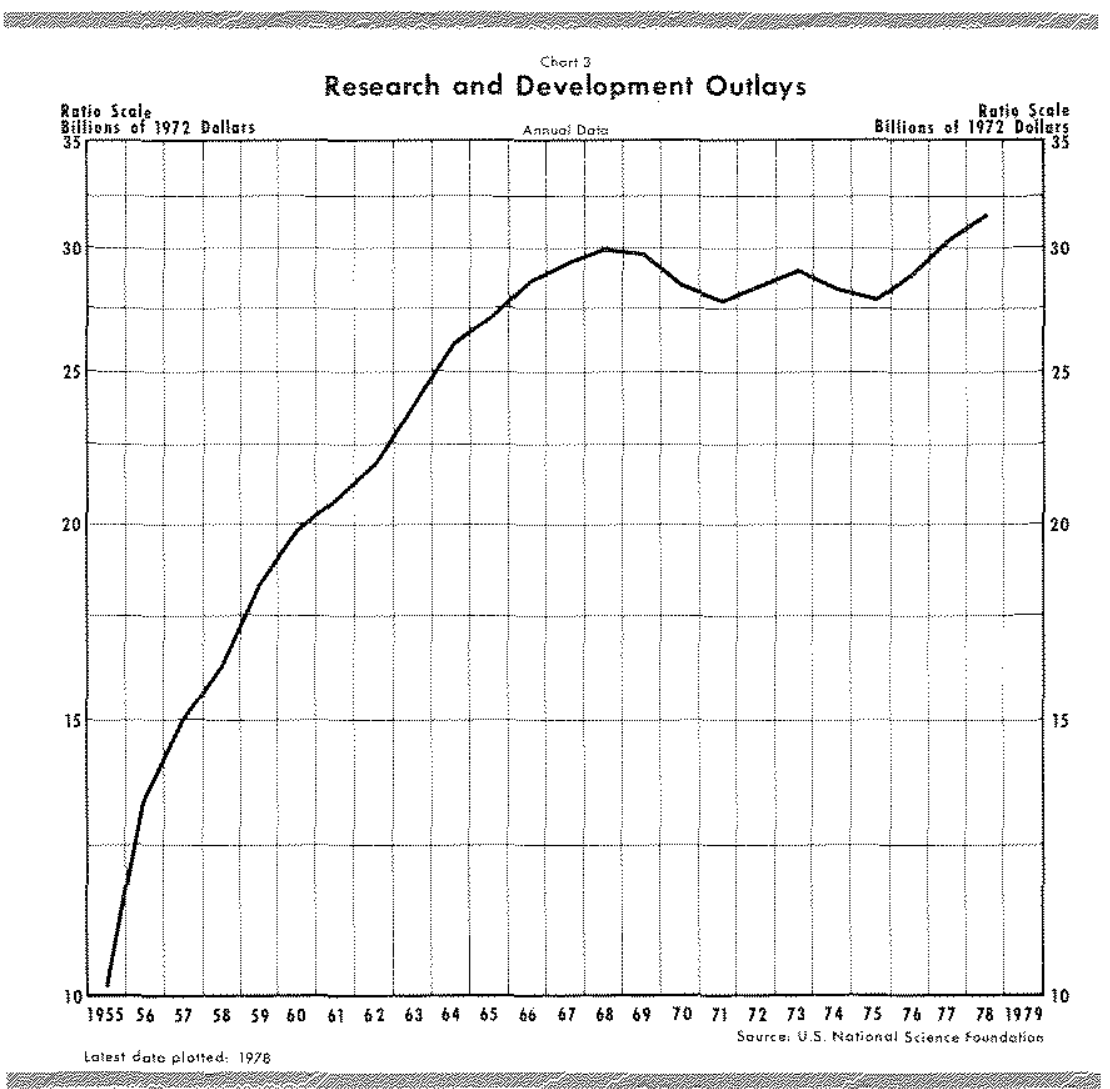

increased business costs associated with unusually high rates of dishonesty and crime. ${ }^{20}$ The first two of these factors, under the general category of increased government regulation, have been cited by many analysts as a significant force in reducing American productivity.

Denison contends that these factors divert real resources from the production of measured output. He estimates the effect of these forces, however, by assessing their impact on output rather than on measured inputs. Furthermore, he finds that over the period 1969-75 these factors reduced productivity growth by an average of .26 percent per year, with pollution abatement accounting for .15 percentage points; health and safety, .07 points; and dishonesty and crime, .05 points. The effect of these factors is quite small when compared to the extent of recent productivity developments.

quantitative impact on recent productivity developments, it is doubtless that a major decline in the contribution of such outlays to productivity has occurred in the seventies. Chart 3 shows estimates of research and development outlays (1972 prices) from 1955-78. From 1955-68, the average annual rate of growth of such expenditures was 7,6 percent. From 1969 through 1976, such expenditures actually were lower in real terms than in 1968. While real research and development outlays rose at a 4.2 percent rate from $1975-78$, the record of the last 10 years is one of substantial reduction in research and development efforts, compared with 1955-68.

Denison has examined three other factors that have adversely affected the trend rate of growth of output per unit of imput. The three factors are: increased costs of pollution abatement since 1967, increased costs for employee safety and health since 1968, and

icy Options," Contemporary Economic Problems 1979 , pp. 17.69, attaches primary importance to this factor in accounting for the slowdown. One of his estimates is that the contribution of advancing knowledge due to formal and informal research and development inventiveness, and diftusion of new technology and capital goods contributed 1.4 percent to anmal productivity growth in $1948-66,1$, percent in 1966-73, and 0.8 percent in $1973-78$. Denison and others have shown that these estimates are probably seriously biased upwards. See Denison, "Explanations of Dedining Productivity Growth," pp. 6-8.

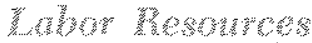

In the past decade, the age and sex composition of the labor force has changed. Many analysts have argued that the labor force has become less experienced on average, as women and young people have become a larger proportion of the nation's labor force, and that this development should have a temporary influence on productivity. ${ }^{2 .}$ As Chart 4 shows, however, growth in the proportion of women in the labor force has not accelerated in the seventies and, since late 1973, the percentage of young people in the labor force has flattened out. If these trends have had any effect on productivity growth, they should have been positive. As the participation rate of women levels off and as younger workers mature, the composition of

29See Edward F. Denison, "Effects of Selected Changes in the Institutional and Human Enviromment Upon Output Per Unit of Input, Survey of Current Business (January 1978), pp. 21-44, "The Puzzling Drop in Productivity," Challenge (May June 1979), pp. 60-62, and "Where Has Productivity Gone, in Willian Fellner, Project Director, Contemporary Economic Problems 1979, 10p. 71-77.

21For example, see George Perry, "Potential Output and Productivity," Brookings Paners on Economic Activity (1:1977), pp. 11-47, and William Fellner, "The Declining Growth of American Productivity: an Introductory Note," Contemporary Economic Problems 1979, pp. 3-12. 
the labor force will become relatively more experienced. ${ }^{22}$ Consequently, changes in the age structure toward older, more experienced workers are expected to have a positive effect on productivity in the next decade.

Another important factor influencing the quality of labor resources and productivity is the health and education of workers. In the past decade, there is no evidence that the trends of rising educational levels and improving health of workers have been reversed, or that the contribution of such influences to productivity have lessened. ${ }^{23}$

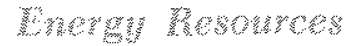

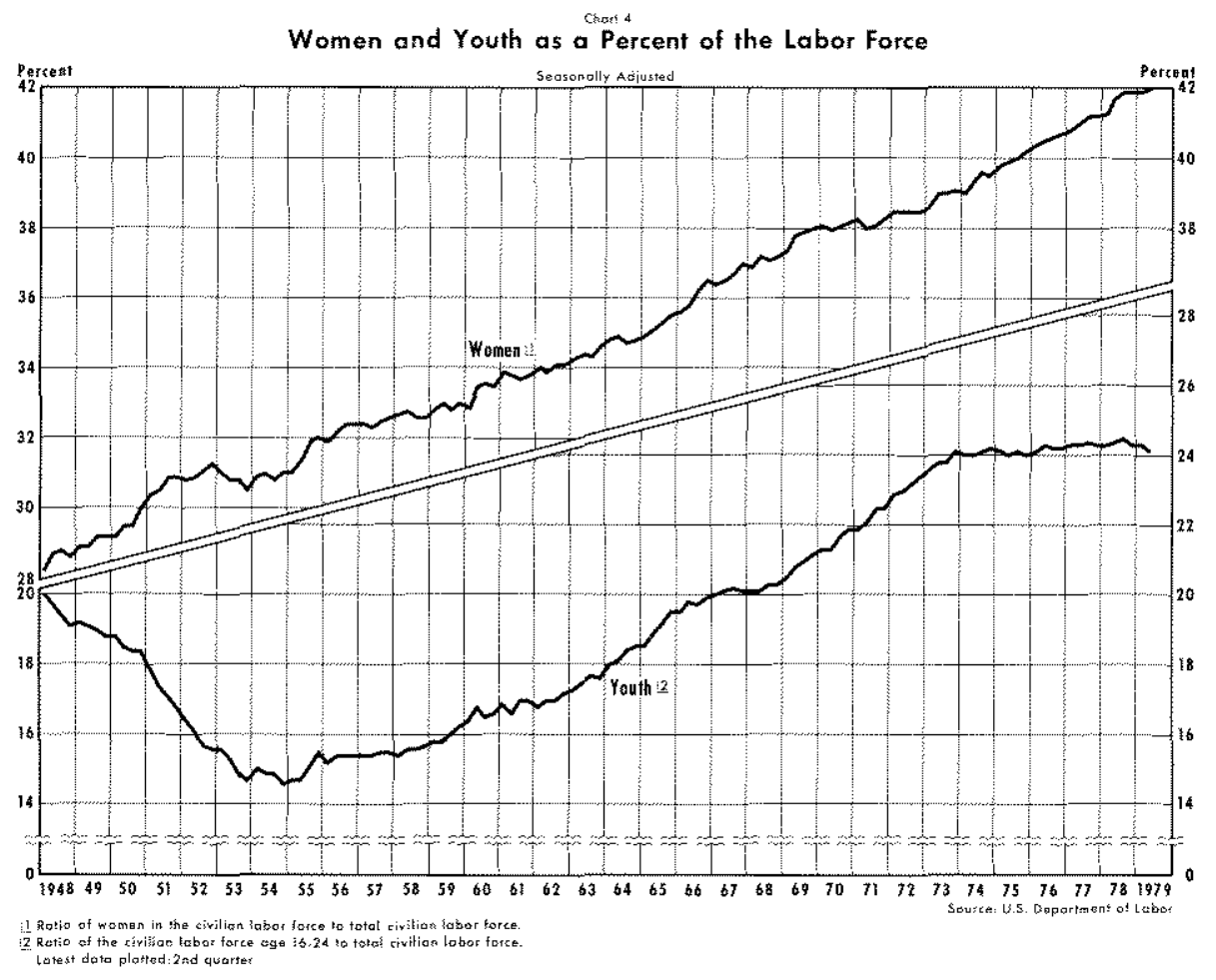

Energy price developments have provided a major shock to the world economy in the seventies and have affected productivity, output, prices, and growth. The extent of the influence on productivity, however, remains a matter of controversy.

Rasche and Tatom have argued that the rise in the price of energy resources relative to that of business output reduced the economic capacity of the business sector, raised prices of output, and reduced productivity of existing capital and labor resources. ${ }^{24}$ These effects stem from efforts to economize on energy in production by substituting the use of other resources. For exanple, they estimate that the increase in energy costs in 1974 alone reduced labor and capital productivity by about 4 percent. For the 1973-78

22It is difficult to assess the importance of the composition of the labor force on productivity. For example, attempts to assess the role of the age structure of the labor force on output by including variables to control for it in a production function framework are often unsuccessful in that such variables are not statistically significant. See Rasche and Tatom, "Energy Resources and Potential GNP," p. 15.

2s See, for example, Fellner's comments on education in "The Declining Growth of American Productivity," p. 8 .

24See Rasche and Tatom, "The Effects of the New Energy Regime on Economic Capacity, Production, and Prices, "Energy, Resoures and Potential GNP," and "Potential Output and Its Growth Rate - The Dominance of Higher Energy Costs in the 1970s," U.S. Productive Capacity: Estimating the Utilization Gap (Washington University: Center for the Study of Americar Business, December 1977), pp. 67106.

period, higher energy prices reduced the growth rate of labor productivity by 1.3 percent per year, irrespective of the indirect effects of energy costs on productivity due to energy-induced reductions in capital formation. By lowering productivity, higher energy costs led to a decline in the demand for other resources. This decline, in turn, was reflected in a fall in real wages and a reduction in firms' desired capitallabor ratios. The observed decline in the capital-labor ratio since 1972 can be explained almost entirely by energy price developments alone. ${ }^{25}$

Other analysts have argued that the effect of increased energy prices on the economy has been much smaller. For example, Fellner attributes only .3 percent of the 1.9 percent per year decline in trend productivity growth from the 1948-73 period to the 197377 period to the shift of production away from energy. using methods. ${ }^{20}$ Denison points out that the timing

\footnotetext{
25See Tatom, "Energy Prices and Capital Formation," and Hudson and Jorgenson, "Energy Prices and the U.S, Economy." They have produced similar results for the impact of higher energy prices on capital formation and, consecuently on productivity. Others have provided support for relatively large short-run effects of changing stpplies of energy as reflected in relative prices of energy. See Clark, "A New Measure of Potential Output," and Jacques R. Artus, "Measures of Potential Output in Manufacturing for Eight Industrial Countries, 1955-78," International Monetary Funds Staff Papers (March 1977), pp. 1-35.

20See Fellner, "The Declining Growth of American Produc-
} tivity," p. 6. 


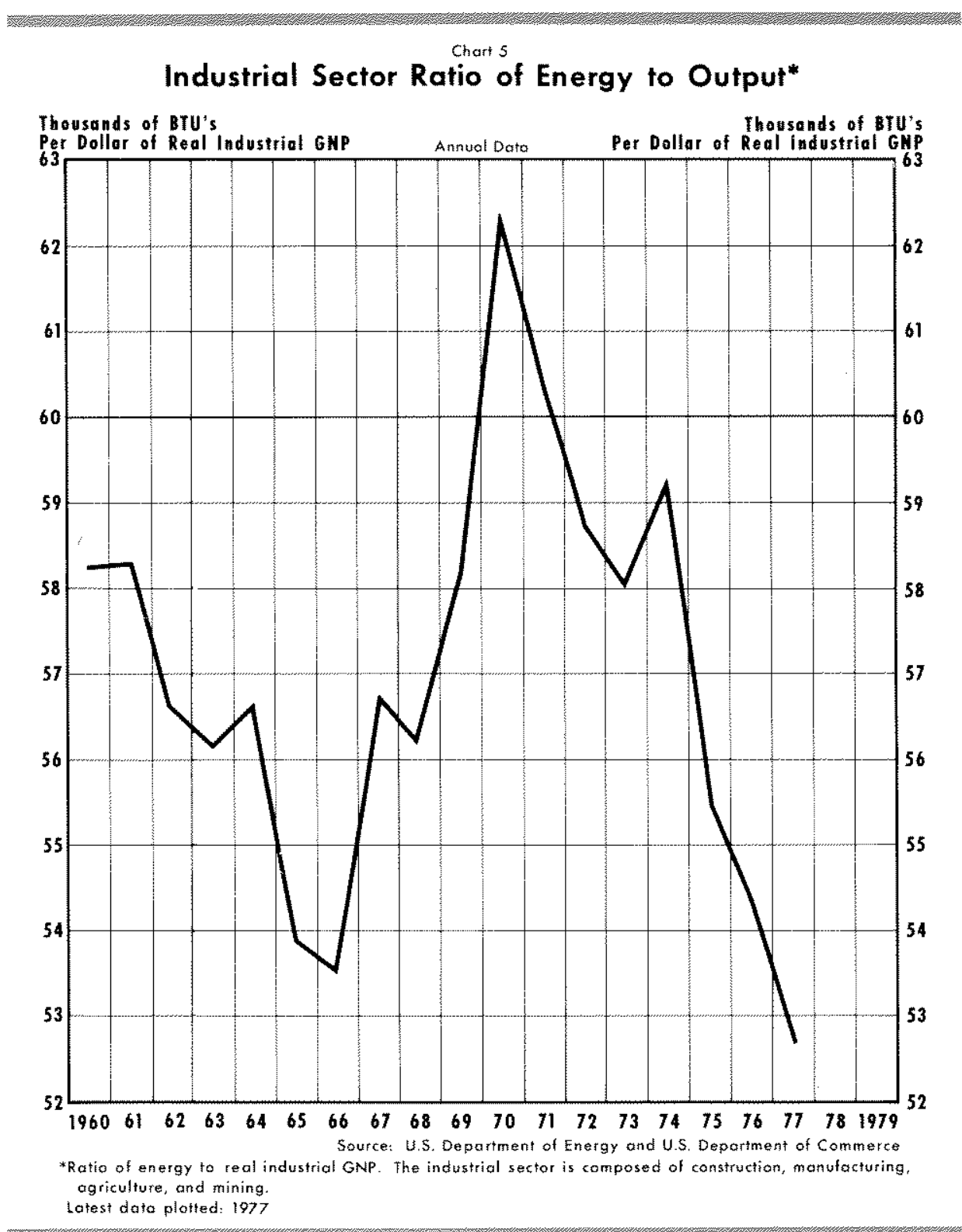

used per unit of output would have had to occur. ${ }^{28}$ Likewise, both have noted that the reductions in energy use that followed the sharp rise in energy prices in 1973-74 were quite small, although both also have acknowledged the difficulty of obtaining meaningful data on energy used by business.

Perry claims that energy used per unit of output in the business sector declined 10.2 percent from 1973 to 1976, while the trend in such reductions from the past alone would have generated a 5.3 to 7.3 percent reduction in energy usage. Thus, he claims that energy price developments reduced energy use by only 2.9 to 4.9 percent over this period. Similarly, DeLeeuw, citing ratios of total and industrial energy consumption to total and industrial real GNP which show a downward trend from 1970-73, argues that this negative trend did not accelerate after 1973.

of energy price developments coincides with that of the adverse productivity developments. Nevertheless, he insists that a more reasonable estimate of the effect of higher energy prices on productivity is 0.2 percent for the period 1973-76, the upper bound of the size of the effect as discussed by Perry. ${ }^{27}$

Both Perry and DeLeeuw have argued that for productivity to have been adversely affected by energy price developments, a significant decline in energy

27See Denison, "Where Has Productivity Gone?" p. 76, "The Puzzling Drop in Productivity" p, 62, and "Explanations of Decining Productivity Growth," pp. 15-18 and Ceorge L. Perry, "Potential Output: Recent Issues and Present Trends," in U.S. Productive Capacity: Estimating the Etitization Gap, pp. 6-12.
Chart 5 shows the ratio of industrial energy use (E) to "industrial" real GNP, where the latter is the real GNP originating in manufacturing, construction, agriculture, and mining sectors for the period 1960-77. This ratio declined after 1970 , as DeLeeuw and Perry point out. There is no apparent trend in this ratio, however, over the longer period 1960-72. A simple regression of the logarithm ( $\mathrm{ln}$ ) of this ratio over the period $1960-72$ fails to reveal a significant negative time trend when the effects of changes in the rela-

2ESee Frank DeLeeuw, "Comments on Rasche and Tatom," in U.S. Productive Capacity: Estimating the Utilization Gap, pp. 137-45.

woThe energy data is taken from U.S. Department of Energy,

Federal Energy Data System (FEDS) Statistical Summary.

This data series is available from 1960-77. 
tive price of energy and cyclical variations in the ratio are taken into account.

The estimated equation, together with one that omits the time trend, is shown in Table 1. The price of energy, $P_{e}$, is measured using the producer price index for fuel, related products, and power deflated by the implicit price deflator for private business sector output. The cyclical adjustment variable, UN, is the difference between the unemployment rate of the civilian labor force and a measure of the unemployment rate under high-employment conditions. ${ }^{30}$

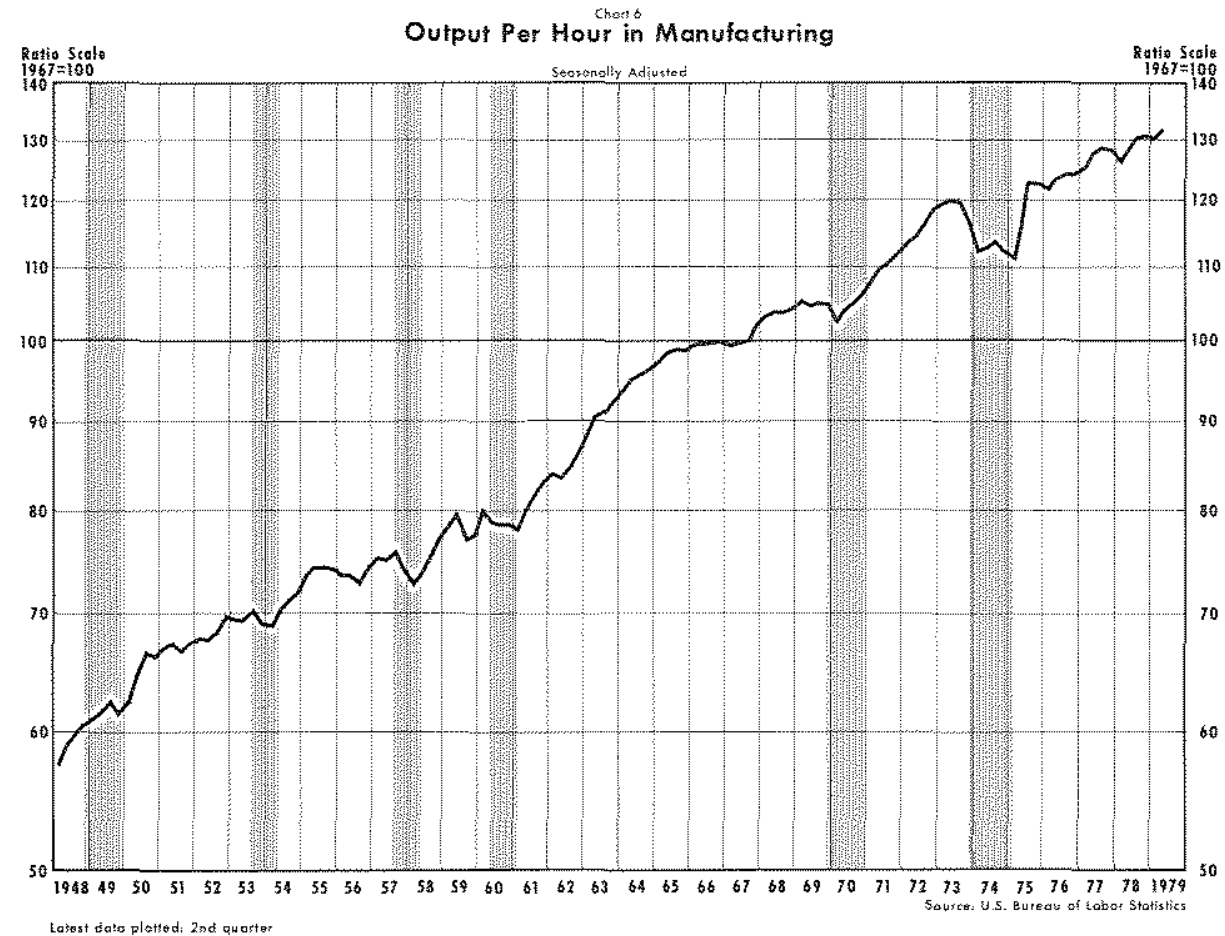

The most notable features of these estimates are the size and siguificance of the relative price coefficient which indicate that the energy ratio is considerably more sensitive to prices than either Perry or DeLeeuw believe. In addition, the statistically

Table :

The Industrial Energy Ratio

$(1960-72)$

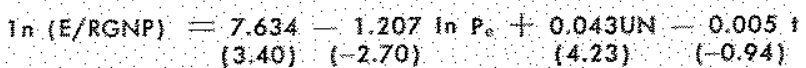

$R^{2}=0.72$

$D W=150$

$s . E=0.020$

In(E/RGNP) $=5.701-0.8251 n P_{2}+0.039 \mathrm{UN}$

$(6.34) \quad(-4.4) \quad(4,22)$

$\mathrm{R}^{2}=0.68$

D. $W=13$

$S E=0.025$

30 The full-employment unemployment rate is that prepared by Peter K. Clark, "Potential Output in the United States 19481980 ," U.S. Productive Capacity, Perry uses the ratio of real GNP to his estimate of potential real GNP which is highly correlated with such a measure of excessive unemployment. It should be noted that when the equations in Table 1 are estimated with the Cochrane-Oroutt technique, the antocorrelation coefficient is not significant. Thus, antocorrelation can be rejected. significant positive coefficient on the excess unemployment rate suggests that the failure of the energy ratio to decline more substantially after 1973 is partly due to the unusually high levels of unemployment in 1975-77. Apparently, energy usage contains a significant overhead component that is insensitive to cyclical variation in output. This contrasts sharply with Perry's negative cyclical coefficient. ${ }^{31}$ Finally, since the time trend is insignificant, assessing energy reductions relative to a negative trend understates the extent of energy reductions after $19733^{32}$

WThe cyclical sensitivity of the energy ratio is essentially an empirical question since one could argue that over the cycle some firms, such as utilities and metal producers, are able to meet temporarily high dernand using less efficient (especially with regard to energy use) plant and/or equipment, and this capital, in tum, is the frot to be laid off during recessionary sales periods. If this effect dominated the use of overhead energy, the energy ratio would be reduced by slack in the economy. On the other hand, the energy producing sector is the most energy intensive production sector. Given the rise in the relative price of their products due to reductions in the availability of other energy sources, some firms would temporarily have an incentive to expand the use of plant and equipment that would otherwise have been obsolete. This effect would raise the energy ratio during the recent slack period.

32The White Howse, Fact Sheet on the President's Program, reprinted in Dally Report for Executives, (April 5, 1979), supplement $\mathrm{p}$. 4 , points out that industrial energy use has dropped by 6 percent while output increased 12 percent since 1973 . This represents a drop in the ratio of about 18 percent. 
Estimates such as those in Table 1 should be viewed skeptically, however. First, as Perry and DeLeeuw point out, the data are problematical ${ }^{33}$ Second, the data cover only direct energy purchases and not the energy component of intermediate products purchased from other industries including transportation. Third, the energy measure is in Btu equivalents rather than an index of the quantity of energy which is compatible with the producer price index for energy.

Most important, however, the size of the price effects on the energy-output ratio is unimportant to the hypothesis that relates energy price developments to the sharp decline in productivity in 1974 and its subsequent slow growth. The Rasche-Tatom estimates of the effect of the relative price of energy resources on productivity apparently are not biased by implicit assumptions about energy demand. If the assumptions introduced such biases, they would be detected in other coefficients of the model estimated. In this regard, it is curious to note that, if energy use is less price sensitive than the approximation used by Rasche and Tatom implies, their estimate of the energy and energy price elasticity of output would be too small, not too large.34 Thus, the claim of a low price elasticity of demand for energy made by Perry, DeLeeuw, and Denison would reinforce the RascheTatom conclusions if it were correct.

In a related fashion, some have argued that productivity developments in the manufacturing sector have not been unusual. ${ }^{35}$ if increased energy prices are an important causal factor in the productivity decline, they should produce a slowing in manufacturing as

33 For example, the regressions end in 1972 because the indus* trial sector energy use data in the U.S. Department of Energy, Monthly Energy Review, teported since 1973 , show a lower level of energy use in 1973 . The nore recent data also show that energy use declines much more rapidly from 1973-78 than in the Federal Energy Data System estimates.

34See Rasche and Tatom, "Energy Resources and Potential GNP," Appendix II, p. 23. Denison, "Explanations of Declining Productivity Growth," pp. I6-17, criticizes the price sensitivity assumption while arguing that the energy price elasticity of output must be smaller than Rasche and Tatom estimate.

35See, for example, "Behnd the Slump in Productivity Growth," Morgan Guaranty Survey (November 1978), pp. well. In fact, the evidence from the manufacturing sector supports this explanation.

Productivity growth in the manufacturing sector has slowed relative to its past trend (see Chart 6 ). From 1948 to 1973 , manufacturing sector output grew at an average annual rate of 3.8 percent, while hours grew at a 1.0 percent rate. From 1973 to 1978 , manufacturing output growth slowed to a 1.7 percent rate and hours growth declined at a 0.1 percent rate. Consequently, output per hour in manufacturing slowed from a 2.8 percent rate of growth to a 1.6 percent rate. Comparable figures for the private business sector show a decline in growth of output per hour from a 2.9 percent to a 1.0 percent rate. While the decline in the growth rate in manufacturing is smaller, this
Production Functions 10 . Manufacturing and The Private Business Sector $(19,8,1976)$

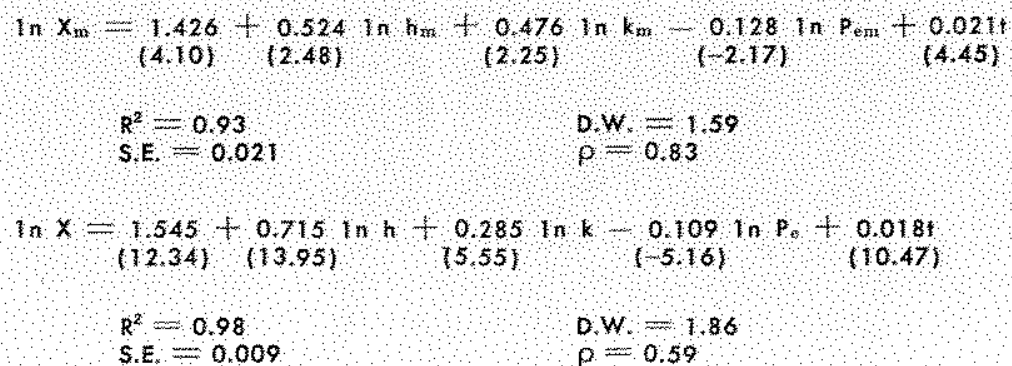

does not imply that the energy price effect observed for the private business sector was smaller or absent in manufacturing.

An estimate of the Rasche-Tatom production function for manufacturing shows that the energy effect on manufacturing is essentially the same as that for the private business sector. ${ }^{30}$ Table 2 shows estimates of PBS ontput $(X)$ and manufacturing output $\left(X_{m}\right)$ for the period 1948-76. In each case, output is a function of hours employed (h), the product of the sector's lagged net capital stock and the Federal Reserve Board capacity utilization rate $(k)$, and the relative price of energy in each sector $\left(P_{e}\right)$, which is found by deflating the producer price index for fuel and related products and power by the implicit price deflator for output in the respective sectors. There is little difference between the size of the effect of the relative price of energy on the private business sector

36The theory and deviation of the equations estimated are discussed more fully by Rasche and Tatom, "Energy Resources and Potential GNP." 
or on manufacturing output. Furthermore, the effect is statistically significant at conventional levels in each case. $^{3 i}$ The smaller decline in productivity growth in manufacturing apparently results from the fact that, while the growth of the net capital stock in manufacturing slowed after 1973, it grew faster than hours employed. Growth in the capital stock per hour of all persons employed slowed for the private business sector during 1973-78, but accelerated in manufacturing. ${ }^{38}$

The rise in the relative price of energy was largely due to OPEC actions since 1972; the relative price of energy rose by a similar amount on a worldwide scale, except to the extent that various nations may have offset the increases by lowering their specific taxes on energy products. Consequently, if the energy priceproductivity hypothesis is correct, one would expect to observe adverse productivity developments and slower capital accumulation in other nations.

Table 3 shows the trend growth rate for 11 industrial countries from $1960-73$ and the average annual growth rate for each country from 1973-78, except for the Netherlands and Belgium where growth rates are computed through 1977 . In each country, productivity growth declined in the later period. In half the foreign countries, the reduction in the five-year average annual rate was more than the standard error of the prior trend-adjusted annual growth rate (Canada, Sweden, United Kingdom, Italy, and Japan). In Italy and Sweden, the reduction was more than twice the standard error of the prior annual growth rate. The pattern of the reduction also conforms to the U.S. experience. In every country but West Germany, pro-

3TThe estimate of the energy elasticity of output from the equations in Table 2 is 11.4 percent in the manufacturing sector and 9.9 percent for the private business sector. Denison's claim that this elasticity must be larger in manufacturing appears to be correct. The difference is not statistically significant, however, since the standard error for the mantfacturing elasticify is 5.2 percent, while that for the private business sector is 1.9 percent. See Denison, "Explanations of Declining Productivity Growth," pp. 16-17. The coefficient on hours in the manufacturing sector is low, given that the share of labor cost for the manufacturing sector during the sample period averaged 69.9 percent. The implied hours elasticity of output in Table 3 for manufacturing is only 46.5 percent, but given its standard error of 18.7 percent, the laypothesis that the hours elasticity and labor share are equal cannot be rejected at the 95 percent confidence level. When the equations in Table 3 are estimated with the output elasticity of hours constrained to equal the average shares of labor cost during the sample period, the estimate of the energy elasticity of output is 9.9 percent in both sectors and significant. Moreover, an Fi-test of this constraint fails to reject it at the 5 percent significance level.

38 When a second time trend is included in the equations in Table 2 to allow for the slowing in the rate of technological change after 1966 discussed earlier, it is not statistically significant at the 20 percent significance level in either case.
Toble 3

Productivity Growth Rates for 11 Industrial Nations (output per hour)

\begin{tabular}{|c|c|c|c|}
\hline & $\begin{array}{l}\text { Annuol Growit } \\
\text { Jond } \\
196073\end{array}$ & $\begin{array}{l}\text { Neroge Anmol } \\
\text { Growth Rofe } \\
1973.78\end{array}$ & Difference \\
\hline United siales & $\begin{array}{l}2.8 \% \\
12.81 \%\end{array}$ & $17 \%$ & $1 \%$ \\
\hline Belofum & 13.5 & $64 \%$ & 0,6 \\
\hline Qnoda & $\begin{array}{l}4,2 \\
121\end{array}$ & 2.5 & 19 \\
\hline Denmats & $(2,2)$ & 4,6 & 26 \\
\hline Netherlonds & $(3.6)$ & $48 *$ & 28 \\
\hline Sweden & $\begin{array}{l}67 \\
(12)\end{array}$ & 13 & 52 \\
\hline United Krigdon & $\begin{array}{l}1.0 \\
200\end{array}$ & 02 & 38 \\
\hline rance & $\begin{array}{l}59 \\
1151\end{array}$ & 47 & 12 \\
\hline West Gernony & 54 & 50 & 0.4 \\
\hline naly & (13) & 26 & 40 \\
\hline $\mathrm{Japan}$ & $\begin{array}{l}99 \\
(40)\end{array}$ & 3.5 & 0.4 \\
\hline
\end{tabular}

(Figanes ho yarentheses are standard error of annual growth rate after adjustirient for trend

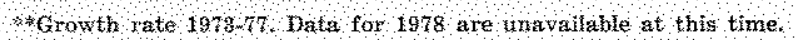

SOURCE, U, S Department of tabor.

ductivity growth was more than one standard error below the prior trend during 1974 or 1975 . In 8 of the 11 countries, productivity growth in 1974 or 1975 declined by more than twice the standard error of the 1960-73 trend-adjusted growth rate (the exceptions are West Germany, the Netherlands, and Denmark). ${ }^{39}$

39 The worldwide decline in productivity growth has also been noted recently in "Whatever Happened to Productivity?" The Economist (August 25-31, 1979), pp. 60-61. As in the case of manufacturing above, it is possible that the labor productivity dectine has been partially avoided in countries such as West Germany and Belgium by institutional arrangements such as "indexing" which keep real wages from falling and lead to faster capital growth relative to employment. Suck growth is manifested primarily by negative or slow employment growth. 
Finally, the rise in the relative price of energy led to incentives to reduce the desired capital-labor ratio in production through a reduced pace of capital formation. Again, this would be expected to occur worldwide. A recent report by the Bank for International Settlements shows that for the United States and five of the foreign countries in Table 3, real nonresidential fixed investment slowed dramatically after $1973 \mathrm{com}-$ pared with a 1955-73 trend. In the five foreign countries, such investment was virtually flat from 1973 to 1978 , compared with annual trend rates prior to 1973 of 15.5 percent in Japan, 5.3 percent in Italy, 6.5 percent in Germany, 7.9 percent in France, and 5.8 percent in the United Kingdom. ${ }^{40}$ Capital formation patterns are similar in the other five foreign nations. ${ }^{41}$ In Bel* gium, real nonresidential capital formation slowed from a 5.2 percent average annual rate of growth in 1965-73 to a 0.3 percent rate in 1973-76. Comparable slowings occured in Denmark, $(4.7$ percent to -1.0 percent) and the Netherlands ( 4.5 percent to -2.3 percent). Data available through 1978 indicate that real nonresidential gross capital formation slowed in Sweden from a 3.6 percent rate in $1965-73$ to a -1.3 percent rate in 1973-78. In Canada the slowing was smaller: from a 4.6 percent rate in $1965-73$ to a 3.1 percent rate in $1973-78$. Thus, two of the major implications of the energy price rise in the seventies appear to be bome out in other nations as well.

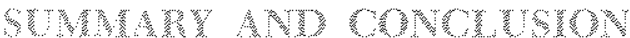

Productivity growth declined substantially during the seventies. Many analysts, regarding the decline as a cyclical phenomenon which reflected unusually high levels of unemployment, did not recognize the seriousness of the problem. In recent months, however, it has become more widely recognized that the productivity problem of the seventies is not a temporary cyclical aberration. Nonetheless, the source of the productivity problem remains controversial.

Economic theory suggests several sources of the problem. With the possible exception of energy price developments during the decade, however,

\footnotetext{
40 See Bank for International Settlements, Forty-Ninth Atrual Report (Basle, June 1979), p. 28. The United States shows the most favorable growth of real nonresidential fixed investment relative to the prior trend when compared with the five other nations. I am indebted to Allan $\mathbf{H}$. Meltzer for calling my attention to this dranatic evidence.

41The data used for these countries is fixed capital formation less residential construction, both in 1970 prices, from the OECD, National Accounts of OECD Countries, Vol, II, 1976. For the $1973-78$ period, the data (in 1975 prices) for Sweden and Canada is from the OECD, Quarterly National Accounts Bulletin, $1978 / \mathrm{IV}$ and $1979 / \mathrm{I}$ issues.
}

no single factor appears to account for the entire problem. While the changing composition of the labor force has been exroneously tagged as the main factor adversely affecting productivity in the seventies, the relatively slow pace of capital formation, including research and development capital, has quietly played an important role in productivity's decline. In addition, the diversion of capital formation from market oriented production to government-regulated goals (such as clean air, occupational health and safety) has been a contributing factor.

The reasons for the slowing of capital formation are as diverse as those that account for productivity developments. Both the increased relative cost of purchasing new plant and equipment and the higher relative cost of operating capital account for a large part of the slowing. These, in turn, are largely due to energy price developments. Inflation and uncertainty about future inflation have also provided strong disincentives for business investment. Much of the disincentive effect of inflation arises through the tax system, but high inflation rates also increase the variability of inflation, which adds to the riskiness of business ventures. Coupled with increased risk arising from growing government influence in the marketplace, risk premiums built into the costs of funds have escalated, further reducing capital formation incentives.

The influence of some of the factors affecting productivity in the seventies may be reversed in the eighties. For example, the sharp acceleration of government regulation in the seventies, to the extent it represented substantial "start-up" requirements of new programs, may slow in the coming decade. The labor force will tend to become more experienced in the eighties as the proportio: of young workers declines and participation rates of women level off. Barring further disruptions, large increases in the relative price of energy are less likely since pricing decisions of OPEC appear to be based upon major changes in market structure such as the formation of the cartel or production policy changes in member countries. In addition, such increases will become increasingly limited by the competitive cost of alternative sources of energy. In spite of such favorable possibilities, however, other adverse factors influencing both capital formation and productivity growth remain. Moreover, the substantial losses of productivity in the seventies are not likely to be recouped without considerable effort.

The list of possible policy options to restore productivity growth is quite long. Essentially it includes any 
efforts that increase incentives to improve labor skills, increase the quantity and quality of plant, equipment, research and development, and increase incentives to produce and utilize energy resources efficiently. Most of the proposals involve cutting various taxes or removing regulatory restraints to stimulate the supply of resources and output in the economy.

Monetary policy can also be useful in the promotion of productivity growth. Inflation and its variability re- tard the expected returns from investment and increase risk. Since inflation depends principally upon the rate of growth of the money supply, a policy which obtains lower and more stable growth rates of the money stock would enhance productivity growth. The most practical means for removing variability of monetary growth and achieving a lower targeted rate of growth is to conduct policy to achieve targets for the monetary base rather than targets for interest rates.

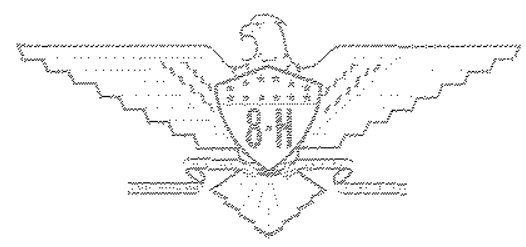

